I. Kotsev, D. Dimitrov, V. Peychev

Institute of Oceanology «Prof. Fridtjof Nansen» Bulgarian Academy of Sciences, Varna, Bulgaria

\title{
RECENT TRENDS IN STATE OF LANDSCAPES AND SHORELINE DYNAMICS IN BULGARIAN SECTOR OF THE BLACK SEA
}

\begin{abstract}
The article analyzes the contemporary processes of natural and human-induced shoreline dynamics between cape Kaliakra and cape Emine, Bulgarian Black Sea coastal zone. Main accent is put on the anthropogenic impact on beach morphodynamics, coastal erosion, sediment transport and accretion influenced by land use changes and technogenic load. The stages of recent landscape transformations since the beginning of the XX century are discussed chronologically. Assumptions are made with reference to existing relationships among coastal geomorphic processes, land use dynamics, levels of anthropogenization and coastal landscape change at the investigated area.
\end{abstract}

Key words: coastal dynamics, erosion rates, solid river runoff, sediment balance, landscape anthropogenization.

\section{Introduction}

The central sector of the Bulgarian Black Sea coast is undeniably among the most intriguing parts of the country. Apart from the inquisitive transitional physiographic imprint that dominates the coastal hinterland between cape Kaliakra and cape Emine, the manifestation of azonal factors have additionally diversified the littoral zone's landscape pattern by predisposing widespread occurrence of sub-longoze complexes, steep erosive cliffs, deep erosive ravines, active landslides, tectonically predisposed land-collapse sectors and relatively large sand strips (Peychev, 2004). The nature conservation value of the cited sector is significant - 17 NATURA 2000 sites are designated here (www.natura2000.moew.government.bg), encompassing more than $50 \%$ of its area. Nonetheless, the negative aspects of the contemporary anthropogenic transformations coupled with erroneous decision-making are indeed the major problem. The unprecedented overdevelopment over the last decades raised the issues concerning sustainable land use, efficient spatial planning, sound environmental protection and proper nature conservation along the Bulgarian Black Sea coast. The ongoing debates openly criticize the lack of integrated coastal manage- 
ment, recognized by many as a major weakness and a rather unacceptable feature of an EU member state. Unfortunately, the ongoing and projected real estate development at the Bulgarian Black Sea coastal zone seldom comply with the proper balance between socio-economic and environmental effectiveness, which implies for future aggravation of the cited issues.

\section{Principal factors for landscape-scale shoreline dynamics at the Bulgarian Black Sea coastal zone}

The coastal zone acts is a filter for sediment materials - part of them are detained in it, while the remainder are transported beyond its boundaries into the deepwater sectors of the marine and ocean basins (Shuiskiy and Schwartz, 1983). The inflowing sediments are divided into suspended load and bed load transport (Rosati and Kraus, 1999). Materials entering as a result of coastal erosion, solid runoff discharge, aeolian drift, biogenic, volcanogenic and glacial activities are transformed through mechanic disintegration and become subject to hydrogenous differentiation according to their grain size and mineral composition (Davidson-Arnott, 2010).

Cliff erosion. Among the most important components of the sediment balance in coastal environments is cliff erosion. More in particular, the term abrasion refers to the process of mechanical wearing down, scraping or grinding away of a rock surface by friction, ensuing from collision between particles during their transport in wind, ice, running water, waves or gravity (Goudie, 2014). Principal morphologic forms shaped by the cited process are the abrasive (erosive) cliff and the abrasion platform (Brossard and Duperret, 2004; Huggett, 2007), the latter commonly being termed abrasive bench in Eastern European geoscientific literature (e. g. Essin et al., 1987; Agarkova-Lyakh, 2011; Bogouslavskiy et al., 2015 etc.).

As a dynamic geomorphic process, the abrasion is associated with various azonal factors which influence both its intensity and diversity of morphologic forms produced e.g. geologic composition, sediment balance, coastal and submarine relief, shore hydrodynamics etc. Among these, a key factor is the lithologic structure and its characteristics, especially the petrographic composition, geochemical properties, as well as the presence of cracks and fissures (e.g. Duperret et al., 2004; Mortimore et al., 2004; Wolters and M?1ler, 2004 etc.). Furthermore, when discussing cliff erosion along the Bulgarian Black Sea coastal zone it should be noted that wind-generated waves affect only the foot of the cliff, while the upper part is typically exposed to other processes, e.g. weathering, erosion by surface streams and underground water_discharge, landslide activity etc. Hence, authors distinguish several cliff types, e.g. abrasive-collapse, abrasive-landslide, abrasive-denudational etc. (e. g. Shuyskiy and Simeonova, 1982; Simeonova, 1992; Keremedchiev and Peychev, 2001 etc.).

Between cape Kaliakra and the town of Kavarna the coast is uniform, composed of white and cream-colored detritus, biogenic and oolitic Sarmatian limestones (Peychev and Dimitrov, 2012) (Table 1). Thanks to the solid lithologic structure the mean rates of abrasion is estimated at barely $0.05 \mathrm{~m} / \mathrm{y}$ (Peychev et al., 2005). Southwestwards, between the town of Kavarna and «Albena» maritime resort the abrasive-landslide coast is composed of Sarmatian calcareous and aleurolite clays, clayish sands and marls (Peychev, 2004), with mean abrasion rates of $0.16 \mathrm{~m} / \mathrm{y}$ (Peychev et al., 2005). The geologic structure of the coast between «Albena» maritime resort and cape Sveti Nikola 
consists of Sarmatian aleurolites, sandstones and clays with mean abrasion rates of $0.14 \mathrm{~m} / \mathrm{y}$ (Keremedchiev et al., 2007).

Further south, the abrasive coast of Varna Bay (cape Sveti Georgi-cape Galata) is composed of Sarmatian sandstones, as well as sandstones and sands with Konk, Karagan and Tchokrak age (Middle Miocene). The abrasion rates in the cited sediments at the coastal sector Kavarna-cape Sveti Georgi is 0,13-0,16 m/y, while in Varna Bay the values reach 0,20 m/y (Peychev, 1998; Keremedchiev et al., 2007).

Recent analyses of the technogenic pressure at the Bulgarian Black Sea coastal zone (e.g. Keremedchiev et al., 2007; Prodanov et al., 2013 etc.) reveal that the mediolittoral sector between cape Kaliakra and cape Galata is characterized by the highest levels of shoreline anthropogenization in the country, reaching as much as $37 \%$ for Varna coastal area (the sub-sector cape Ekrene-cape Galata). Negative consequences of the excessive concentration of hydrotechnical structures here include intensified coastal erosion, human-induced landslide activity and seabed conversion.

The geologic structure of the coastal sector stretching between cape Galata and cape Emine consists of Neogenic sandstones, Sarmatian limestones, Paleogenic sandstones, marls and clays, and at the East Balkan Mountains - of Upper Cretaceous sandstones, aleurolites, argillites and limestones (Peychev and Dimitrov, 2012). The mean abrasion rates in these rocks are $0.16 \mathrm{~m} / \mathrm{y}$ (Peychev et al., 2005). The cited sector is among the best preserved in Bulgaria by means of technogenic pressure.

Coastal source provinces and solid river runoff. Alongside the products of coastal erosion and abrasion, the Black Sea littoral zone is also normally nourished with sediments transported and accumulated by the rivers' runoff (Vikhovanets, 1999). There are 102 rivers along the Bulgarian coast, 19 of which flow directly into the Black Sea, 14 - into coastal lakes where the solid discharge is retained, and the rest 69 are smaller main river tributaries. The water discharge quantities enlisted in Table 2 are determined on the basis of measurements at hydrometric stations covering the period 1935-1979, as well as by using data on surface runoff modulus available for the rivers without hydrometric stations. The total amount of solid runoff discharge into the Bulgarian coastal zone is estimated at $1.070 .000 \mathrm{Mg} / \mathrm{y}$ of which $780,600 \mathrm{Mg} / \mathrm{y}$ represent the volume of sediments discharged by the rivers which run directly into the Black Sea (Dimitrov et al., 2003; Dimitrov, 2010). Nevertheless, it has to be noted that far from all solid river runoff goes into the sea, part of it is deposited in the river mouths, firths and lagoons and thus forming subaereal and subaqueous accumulative forms.

The total area of the Black Sea catchment district is about $15,000 \mathrm{~km}^{2}$. Based on differences in the coastal lithology 3 major source provinces can be differentiated -

Table 1. Coastal erosion parameters

\begin{tabular}{|l|c|c|c|c|c|c|}
\hline \multicolumn{1}{|c|}{ Coastal sector } & $\begin{array}{c}\text { Length, } \\
(\mathrm{km})\end{array}$ & $\begin{array}{c}\text { Mean } \\
\text { erosion rate } \\
(\mathrm{m} / \text { year })\end{array}$ & $\begin{array}{c}\text { Eroded } \\
\text { area, } \\
\left(\mathrm{m}^{2} / \text { year }\right)\end{array}$ & $\begin{array}{c}\text { Eroded } \\
\text { volume, } \\
\left(\mathrm{m}^{3} / \text { year }\right)\end{array}$ & $\begin{array}{c}\text { Eroded } \\
\text { mass, } \\
\times 1000 \mathrm{t} / \text { year }\end{array}$ & $\begin{array}{c}\text { Average } \\
\text { cliff } \\
\text { height }(\mathrm{m})\end{array}$ \\
\hline Cape Kaliakra - Kavarna & 11,0 & 0,05 & 550 & 9460 & 23,8 & 17,2 \\
Kavarna - Albena & 14,3 & 0,16 & 2288 & 36523 & 73,3 & 16,4 \\
Albena - cape Galata & 4,7 & 0,15 & 705 & 7685 & 15,4 & 10,9 \\
Cape Galata - cape Emine & 29,2 & 0,16 & 4672 & 66342 & 136,7 & 14,2 \\
Tot a 1 & 61,0 & 0,13 & 7215 & 12000 & 249,2 & 14,5 \\
\hline
\end{tabular}


Table 2. Solid runoff discharge of the Bulgarian Black Sea river tributaries

\begin{tabular}{|c|c|c|c|c|c|}
\hline River & Inflow into & Length, km & $\begin{array}{l}\text { Watershed area, } \\
\qquad \mathrm{km}^{2}\end{array}$ & $\begin{array}{l}\text { Water discharge, } \\
\mathrm{m}^{3} / \mathrm{s}\end{array}$ & $\begin{array}{c}\text { Solid discharge, } \\
10^{3} \mathrm{Mg} / \mathrm{y}\end{array}$ \\
\hline Kavarnenska & Black Sea & 3.1 & 12.3 & 0.01 & 0.8 \\
\hline Batova & " " & 38.7 & 338.8 & 0.73 & 35.4 \\
\hline Kranevska & $» »$ & 13.9 & 84.5 & 0.36 & 8.0 \\
\hline Devnia & Beloslav Lake & 27.0 & 201.1 & 2.43 & 85.1 \\
\hline Provadiyska & & 119.0 & 2131.8 & 2.05 & 71.0 \\
\hline Sakama Deresi & Black Sea & 6.5 & 16.9 & 0.01 & 0.4 \\
\hline Pasha Dere & » » & 4.9 & 21.3 & 0.02 & 0.8 \\
\hline Kamchia & » & 244.5 & 5357.6 & 19.25 & 462.0 \\
\hline Shkorpilovska & $»$ & 26.9 & 78.7 & 0.34 & 7.5 \\
\hline Kara Dere & $»$ & 6.3 & 17.8 & 0.02 & 0.5 \\
\hline Byala & » & 3.2 & 14.4 & 0.01 & 0.3 \\
\hline Perperi Dere & $»$ & 14.9 & 58.2 & 0.25 & 5.5 \\
\hline Dvoynitsa & $»$ & 52.5 & 478.8 & 2.06 & 45.5 \\
\hline Irakly & $» \quad »$ & 10.3 & 40.4 & 0.17 & 3.8 \\
\hline Total & & & 8769.9 & 27.54 & 726.6 \\
\hline
\end{tabular}

southern, central and northern. Landwards, their boundaries are marked by the hydrographic networks and the drainage basins of the Black Sea tributaries.

The central nourishing province is located between cape Emine and Varna Bay. Its lithologic structure is defined by the Upper Cretaceous and Palaeogenic sediments, represented mainly by Campanian-Maastrichtian limestones, alternated with clayish-calcareous sandstones and marls (Peychev, 2004). The conditions for exporting eroded material from the central province are much favorable and the solid runoff of rivers is larger in comparison to the contiguous southern province.

The northern nourishing province encompasses the coastal part of the Moesian Platform. Here, the Neogenic carbonate complex prevails alongside the loess deposits of Pleistocene age at the uttermost northern part. The terrestrial relief is weakly indented and the river valleys are rather short with small catchment areas. Small quantities of annual rainfalls and the karst relief of coastal Dobrudzha determine the insignificant and intermittent river runoff, and as a result - negligible solid runoff.

Sediment transport and beach morphodynamics. Nourishment properties are a key driver of beach morphodynamics, whose spatio-temporal changes are manifested in accretion and erosion. Hence, crucial elements of a given beach and dune system is the sediment transport, accumulation and redistribution of materials eroded from the coastal source provinces (e.g. Antsyferov et al., 1990; Dimitrov et al., 2003; Masselink et al., 2007; Dimitrov, 2010, etc.).

The majority of the beaches at the Dobrudzhean coastal zone between Bolata Dere ravine close to the village of Bulgarevo and Balchisko Dere ravine near the homonymous town are of sheltered type. Due to the solid lithologic structure of the cliff, there is a deficiency of eroded material in the sediment flow (Popov and Mishev, 1974). As a consequence, the accretion rates are of insignificant values which results in narrower cross-shore profiles. Thanks to their location westwards from cape Kaliakra and the southern exposition, the beaches are well protected from coastal erosion provoked by wind-generated winds coming from the eastern and the northeastern quarters. Nevertheless, due to the narrow cross-shore profiles, they are frequently inundated dur- 
ing storms (Trifonova and Stancheva, 2005). The only exception is Bolata beach formed in front of the homonymous ravine, whose nourishment and greater width are related to the erosion of the nearby sandy limestones and calcareous sandstones (Popov and Mishev, 1974). Several artificial beaches have also been created within the Dobrudzhean Plateau coastal zone, e.g. Kavarna beach, Ikantalaka beach, Balchik beach etc. The manifestation of the two principal dynamic factors here, namely wave activity and sediment transport, has been altered due to construction of hard coastal protection structures built in order to facilitate beach formation and accretion (Prodanov et al., 2013).

Further south, the Albena-Kranevo beach formed at Batova Depression is with prevailing eastern exposition. By analyzing available data on grain size and carbonate content of the surface substrates (Peychev, 2004; Peychev and Dimitrov, 2012) it can be concluded that the northern portion of the sand strip is predominantly nourished by eroded materials transported from the contiguous abrasive-landslide sector, while the southern portion is fed by solid river runoff of Batova and Kranevska. The recent morphodynamic trends at Albena-Kranevo beach are characterized by prevalence of erosion over accretion, reaching net values of $0.63 \mathrm{~m} / \mathrm{y}$ (Dachev and Nikolov, 1977).

The majority of the natural sand strips at Varna coastal area are bound to mouths of gullies and ravines, which act as main sources of sediment material for the regional morphodynamic system. There is a long-term tendency of ubiquitous beach erosion with rates varying from 0.06 to $0.59 \mathrm{~m} / \mathrm{y}$ depending on the beach's location and section. This negative process comes as a consequence of inappropriate geoengineering interventions dating from the 1970's. Such erroneous decisions include placement of concrete panels within the ravine beds with the idea to attenuate the erosion, coupled with hard coastal protection meant to stop cliff erosion and the associated landslide activity. The constructed groins designed to detain sand and hence facilitate the creation of artificial beaches seriously intervened in the natural long-shore sediment transport in the region, whose potential is otherwise significant (approx. 802,000 $\mathrm{m}^{3} / \mathrm{y}$ of eroded material) (Keremedchiev et al., 2007).

Quite alarming are the recent morphodynamic trends of the beaches located north from Varna at sections with presence of hard coastal protection, e. g. Kabakum, Albatros, Golden Sands and Riviera. The sand strips here are progressively eroding due to erroneous geoengineering decisions which do not comply with the properties of the coastal hydrodynamics and the long-shore sediment transport (Dachev and Genov, 1998). Another issue is the disturbed terrigenous nourishment by coastal gullies and ravines, which cannot compensate erosion and leads to imbalance in the sediment budget, especially after extreme storms. Only few beaches are experiencing accretion rather than erosion, e. g. the southern portion of Varna Central beach, Panorama beach, Sunny Day beach, Euxinograde beach etc. (Keremedchiev et al., 2007).

Beaches within the Avren Plateau littoral zone are currently in a state of a dynamic equilibrium thanks to the absence of any anthropogenic interventions by means of ravine systems correction or construction of major coastal protection structures that may attenuate the gully erosion or disrupt the long-shore sediment transport. There are two general directions of the sediment transport, one from north to south from cape Galata towards cape Emine with an estimated potential solid volume of up to $1.100 .000 \mathrm{~m}^{3} / \mathrm{y}$, and another in from east to west from cape Galata towards the inner section of Varna Bay (estimated potential solid volume of $105.000 \mathrm{~m}^{3} / \mathrm{y}$ ) (Keremedchiev et al., 2007). Hence, the coastal zone can be divided into two sub-regions. The first sub-region 
covers the northeastern periphery of the Avren Plateau with Asparuhovo beach being the major sand strip. The accretion processes prevail with rates of approximately $0,54 \mathrm{~m} / \mathrm{y}$. This is due to the construction of a jetty at the northern portion of Asparuhovo beach that partially detains the sediment transport in east-to-west direction from cape Galata towards the navigable canal (Dachev, 2003), connecting Varna Bay with the homonymous lake. The second sub-region occupies the whole eastern (coastal) sector of the Avren Plateau, where the morphodynamic properties of the sand strips are dictated by slight prevalence of erosion over accretion (rates varying from 0,04 to $0,09 \mathrm{~m} / \mathrm{y}$ ) (Keremedchiev et al., 2007). The only exception is Pasha Dere beach characterized by mean annual accretion rates of $0.66 \mathrm{~m}$, which is explained with the greater erosive potential of Pasha Dere in comparison to the nearby ravine systems nourishing the remaining sand strips (Keremedchiev and Peychev, 2001).

The morphodynamic processes at Kamchiysko-Shkorpilovski beach (Kamchia Depression) are dictated by redistribution of the solid runoff of the rivers Kamchia and Fandakliyska by the long-shore sediment transport with north-to-south direction (Dachev and Nikolov, 1977). Other significant sources of sediment material are the intensive erosive-landslide processes at the coastal section near cape Paletsa north from Kamchia coastal zone (Nikolov et al., 1973). First major anthropogenic interventions in the beach morphodynamics occurred in the 1940's when some corrections of the river Kamchia downstream were made. As a consequence, the accretion rates reached excessive values of $2,10 \mathrm{~m} / \mathrm{y}$ for the northern and $1.77 \mathrm{~m} / \mathrm{y}$ for the southern portion of the sand strip (Dachev and Nikolov, 1977). Greater accretion rates at the northern portion of the beach are explained with the intensified erosive-landslide activity within the contiguous section at cape Paletsa that followed after the corrections of the river mouth (Nikolov et al., 1973). Research carried out between 1958 and 1973 registered even grater values of beach accretion for the northern section $-2,92 \mathrm{~m} / \mathrm{y}$, which Dachev and Nikolov (1977) explain with the intensified transportation abilities of the river runoff after the construction of the dykes. Utmost accretion of 7,32 m/y for the above-mentioned period was recorded in immediate proximity to the river mouth, seriously contrasting to the rest of Kamchiysko-Shkorpilovski beach, where erosion rates of $0,12 \mathrm{~m} / \mathrm{y}$ rather than accumulation were taking place. After the construction of four reservoirs upstream in the river catchment basin, erosion at the southern portion of the beach increased drastically and soon reached rates of 1,63 m/y (Dachev and Nikolov, 1977).

Natural sand strips at Kamchia Mountain coastal zone are represented by two comparatively large beaches - Kara Dere and Byala. Their genesis is of local type (Peychev, 2004; Peychev and Dimitrov, 2012) and thereby related to the erosion of the nearby conglomerates and sandstones with Paleogenic and Neogenic age (Stoykov and Pironkov, 1981; Kanchev and Gercheva, 1992). Thanks to the absence of any substantial anthropogenic interventions, these two beaches are presently in the state of dynamic equilibrium (Byala beach dossier, 1992; Kara Dere beach dossier, 1992).

Two major sand strips are present in the littoral zone of Emine Mountain, namely Obzor an Irakli beaches. Their formation is primarily related to the solid runoff of the rivers Dvoynitsa (Obzor beach) and Vaya (Irakli beach). Both sand strips are additionally nourished with terrigenous sediments, delivered by the erosive ravines. The material is subsequently transported and accumulated by the near-shore sediment transport in north-to-south direction. These beaches are currently in the state of a dynamic equilib- 
rium with a slight prevalence of erosion over accumulation (Irakli beach dossier, 1992; Obzor beach dossier, 1992).

Coastal land use dynamics. The contemporary process of extensive anthropogenic transformation of the Bulgarian Black Sea coast dates back to the beginning of the XX century, when in 1908 the first Bulgarian maritime resort, «St. Konstantine and Helena», was founded north from Varna. However, the most drastic anthropogenic transformation of the natural subaqueous environment during the cited period was the digging of the navigable canal connecting Varna Lake with the homonymous bay. Finished in 1909, the subsequent influx of salt water converted the lake basin into a brackish firth, thereby destroying the fresh-water biological assemblages (Ivanov et al., 1961).

The epoch of Totalitarianism in Bulgaria (1944-1989) was associated with drastic changes in the socio-economic life of the country, which inevitably influenced the land use dynamics along the Black Sea coast. The nationalization of the private farmland drove many Bulgarians away from the rural areas into the coastal towns. At the same time, these rapidly became main economic hubs and ports of regional or national importance. Such statement is particularly valid for Varna, often referred as the maritime capital of Bulgaria. Numerous industrial and power plants, factories, commercial zones, a shipyard and a dockyard were built along the shores of Varna Lake and in Varna Bay area during the Socialist period.

Thanks to the excellent climate conditions and the consistent long-term policy of the Bulgarian communist governments oriented towards rapid development of the tourist sector, the country became a well-known Balkan destination for maritime summer recreation. Numerous resorts and recreational areas were established at the Bulgarian Black Sea coast during the Socialist period, including «Tuzlata» near Balchik in coastal Dobrudzha, «Albena» and Kranevo at Lower Batova depression, «Golden Sands» and «Chaika» at Varna coastal area, «Veteran» and «Chernomorets» at the Avren Plateau coastal zone, «Kamchia» and Shkorpilovtsi at Kamchia coast, Obzor and «Irakli» at Emine Mountain coastal area etc. These landscape anthropogenization processes were logically accompanied by construction of new infrastructure. Although carefully planned in general, yet the fast-growing tourist sector led to certain levels of negative impact upon the coastal landscapes. A common feature of the Bulgarian Black Sea coast is that the most valuable nature conservation sites are also the most attractive ones when it comes to recreation. Hence, a few of the resorts and the recreational facilities were built in the vicinity of ecologically sensitive areas, e. g. «Tuzlata» camp site contiguous to the homonymous ornithologically important lagoon (Balchik Municipality), «Albena» resort bordering «Baltata» reserve at Lower Batova depression, «Golden Sands» next to the homonymous nature park at Varna coastal area, «Kamchia» and Shkorpilovtsi close to «Longoza» locality etc.

The second half of the XX century was marked by commencement of organized coastal protection in Bulgaria. The choice of hard defense resulted in the construction of 24 solid concrete groins, jetties, sea walls, moles etc. within the mediolittoral and the shallow sublittoral zone (Resulov, 1989; Stoykov, 1998). Unfortunately, the majority of the geoengineering decisions applied were ill-considered and of insufficient scientific background, or simply copied Soviet models without taking into account the specifics of the local coastal dynamics. Often these constructions were aimed at (or combined with) creation of beaches for the demands of the expanding maritime recreation. Such sand strips with anthropogenic origin were a constituent part of the ambitious national 
plan to provide simultaneously permanent coastal protection and enhancement of the seaside recreational capacity of Bulgaria. As the bitter experience revealed quite soon, these concrete structures and artificial beaches were unable to fulfill the purpose they were made for. What happened was just the opposite. By completely ignoring others, more environmentally friendly options for soft protection, these obsolete measures proved rather erroneous in long-term perspective, leading instead to intensification of the erosion and landslide processes, eventually resulting in persistent destabilization of the shore. (Dachev and Genov, 1998). The significance of the key component of the coastal morphodynamic system, namely the sediment transport and its properties, was seriously overlooked. Indeed, the most important natural providers of terrigenous sediment materials, the coastal gullies and ravines, were sealed through construction of concrete beds as part of the incorrect geoengineering decisions aimed at fighting landward erosion. Concurrently, the highly productive hard-bottom seabed complexes near the coastal protection structures were affected by burial and smothering through intensified sand accumulation and siltation, which in turn led to inevitable conversion into less valuable soft-bottom types of shallow submarine landscapes. These processes are still manifested nowadays within the coastal sector stretching between the towns of Kavarna and Balchik (coastal Dobrudzha), as well as at Varna Bay area.

The contemporary period (1989 - present day) is perhaps the most detrimental for the Bulgarian Black Sea coastal environment. After the overthrow of the totalitarian regime in the country, the majority of the recreational facilities were privatized and subsequently densely overbuilt. Unlike the common trend in Europe, oriented towards environmental-friendly tourism and the widespread increase of the campsites number throughout the continent, most of these grounds along the Bulgarian Black Sea coast were purposely destroyed. Later, the terrains were sold and subsequently converted into hotel resorts, without taking into consideration the carrying capacity of the coastal landscape complexes. The soft-bottom zoobenthic assemblages in the mediolittoral zone are subject to intense anthropogenic pressure, particularly trampling, while the construction of new hydro-technical structures, yacht marinas and fishermen harbors cause additional physical damage and physical loss of shallow seabed habitats (Prodanov et al., 2013). Certain sites were wiped out from the register of the Bulgarian protected areas and scheduled for building. Although sounding illogical for an EU state, most of the coastal settlements and resorts in Bulgaria are still missing any spatial development plans. Where such documents are present, thorough analyses of their content reveal current and projected marine use types that run counter to the conservation value of the contiguous seabed sectors, with Varna coastal area being among the most disturbing examples. Due to exhausted recreational capacity of «Golden Sands» maritime resort, the graphic appendices of Varna General Spatial Plan foresee the construction of several artificial islands inside «Aladzha bank» NATURA 2000 site, four of which lying partially or entirely on top of the geogenic reef that is the primary habitat of nature conservation interest and thereby the main reason for designation of the protected area.

Despite the general tendency for decline of the national economy, today the coastal towns are characterized by rather intensive urban dynamics due to artificial increase of the population. The coastal municipal centers remain attractive destinations for internal migration because of the flexible labor market and better job opportunities there. As a consequence, these towns are considerably expanding their spatial extents, mostly at the expense of former agricultural terrains located nearby. 


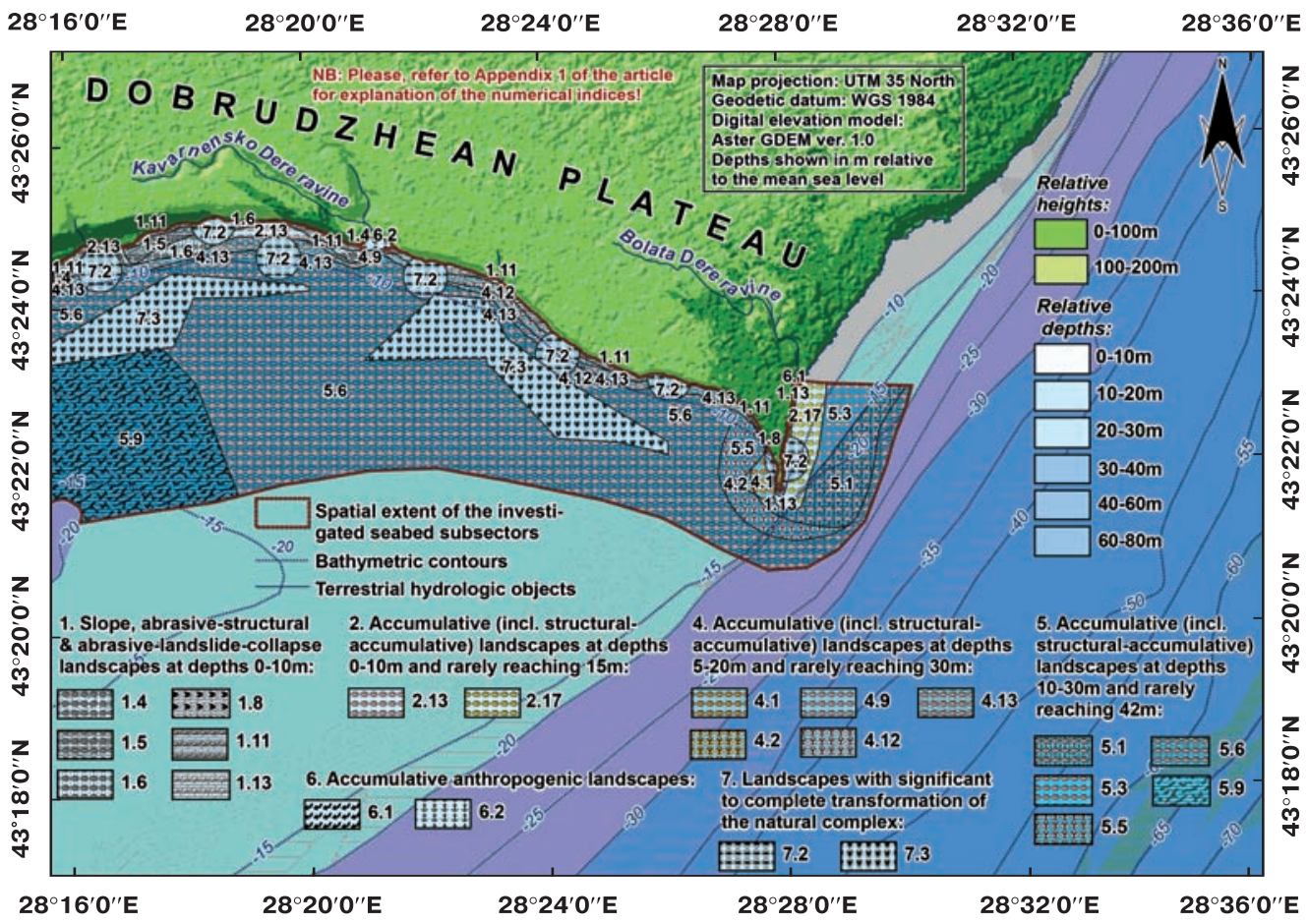

Fig. 1. Submarine Landscapes at Coastal Dobrudzha

$28^{\circ} 2^{\prime} 0^{\prime \prime} E$

$28^{\circ} 4^{\prime} 0^{\prime \prime} E$

$28^{\circ} 2^{\prime} 0^{\prime \prime}$

$28^{\circ} 12^{\prime} 0^{\prime \prime} E$

$28^{\circ} 16^{\prime} 0^{\prime \prime} E$

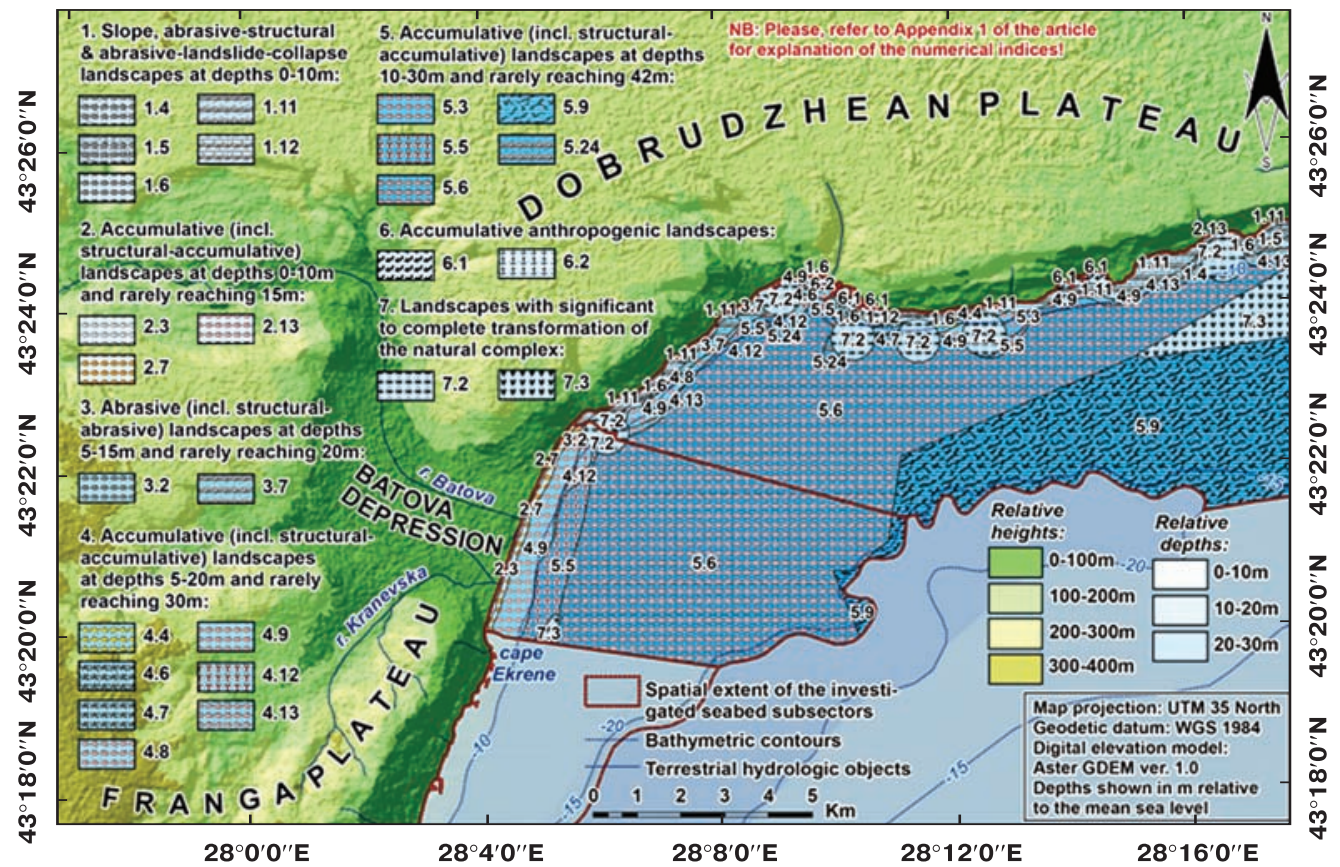

Fig. 2. Submarine Landscapes at Batova Depression 


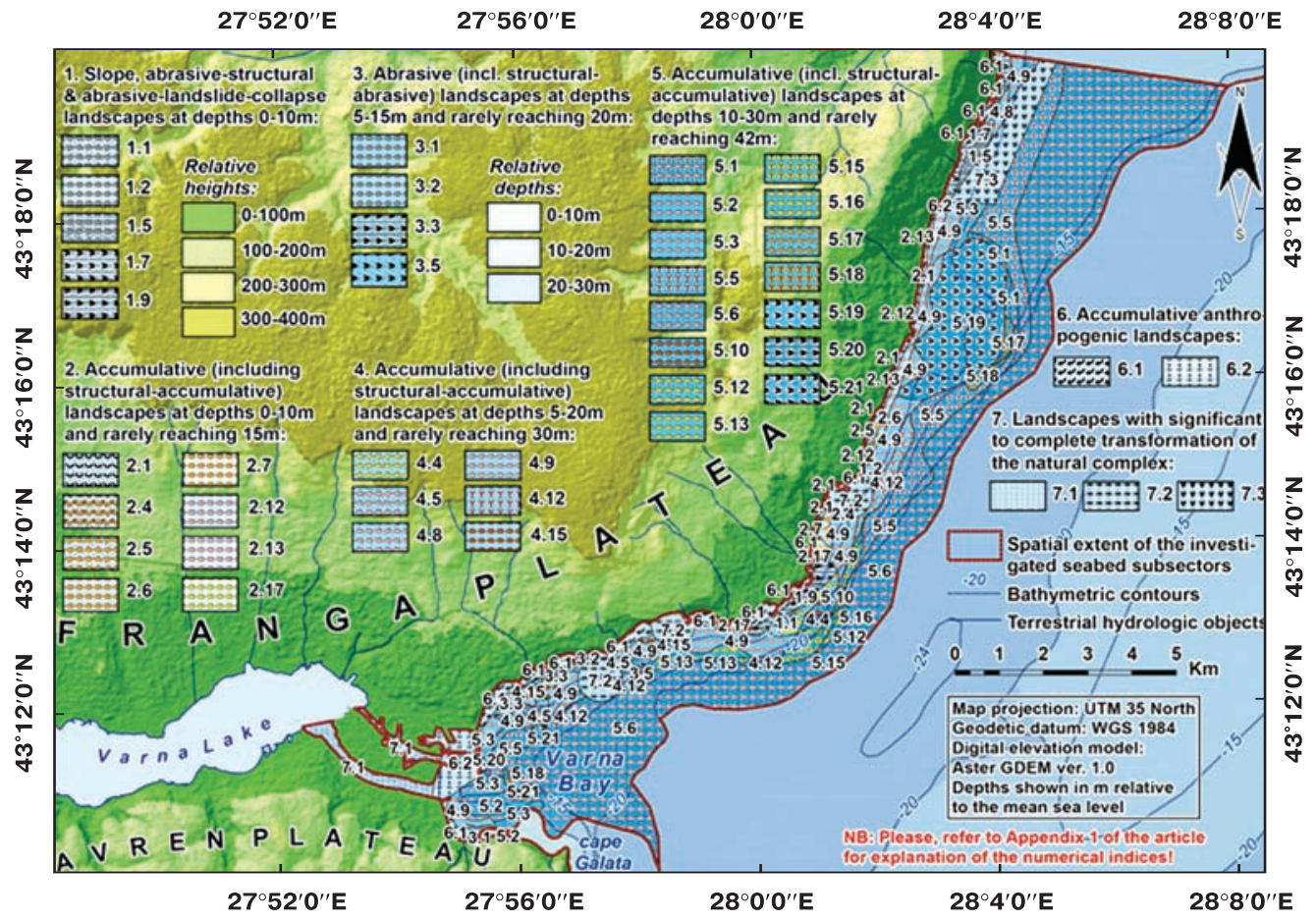

Fig. 3. Submarine Landscapes at Varna coastal area

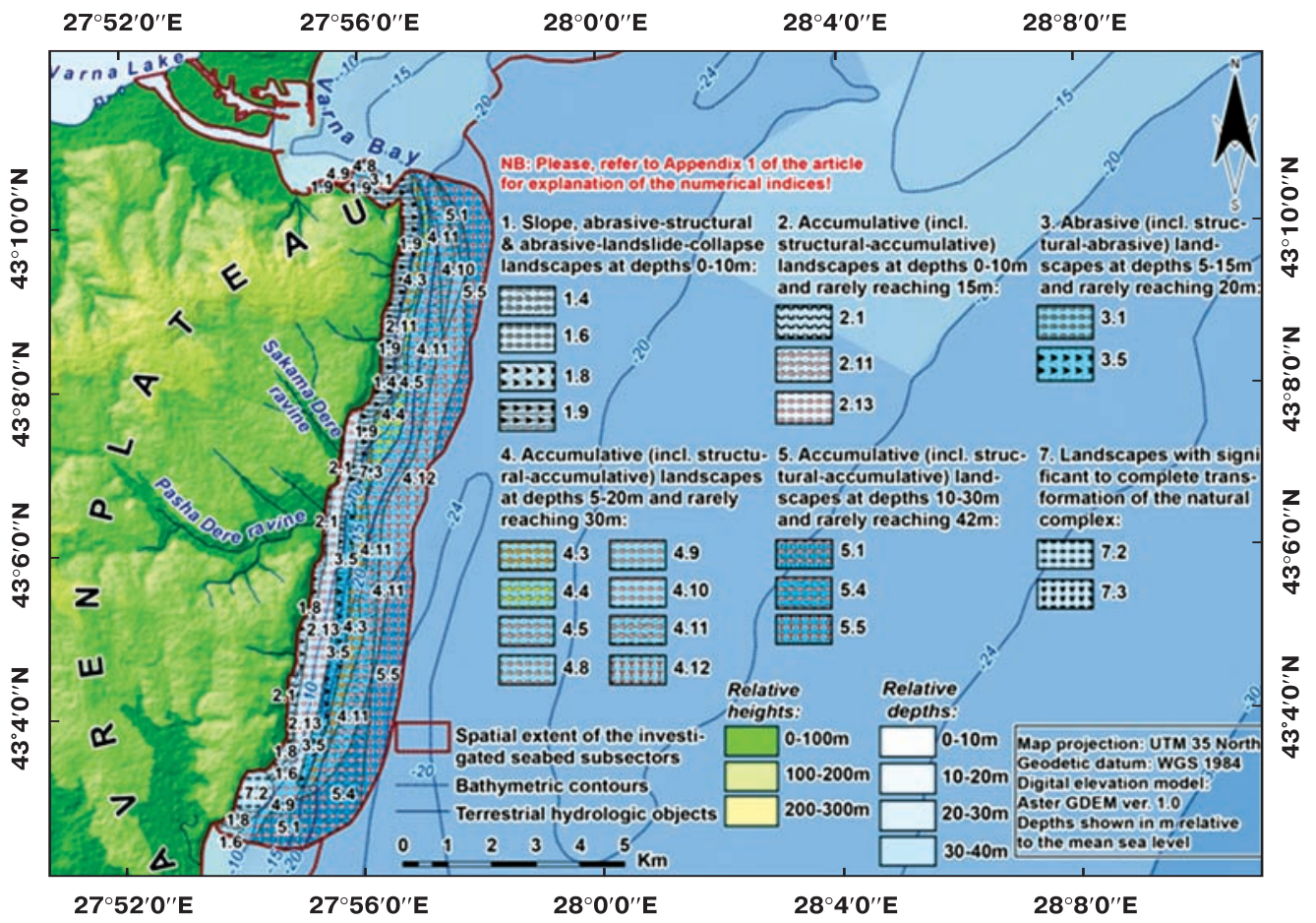

Fig. 4. Submarine Landscapes at Avren Plateau coastal area 


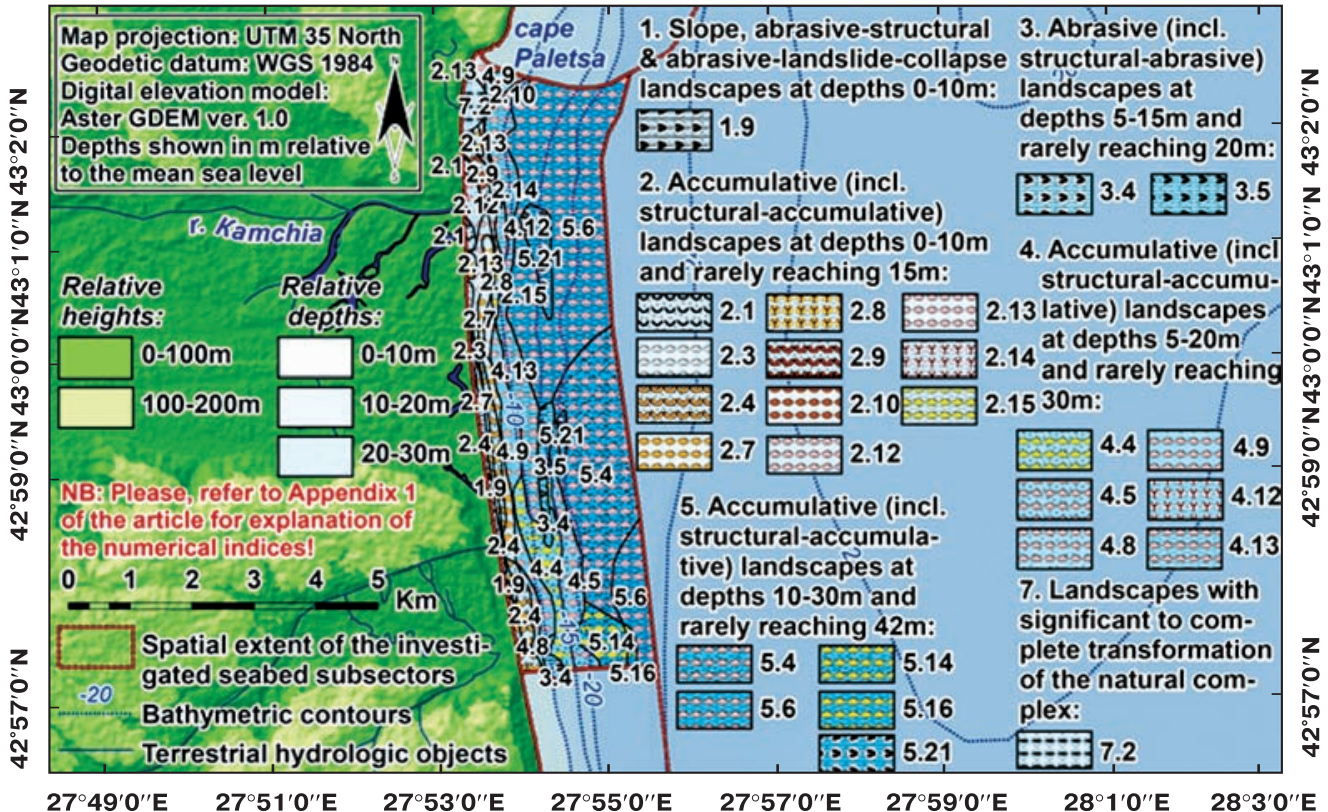

Fig. 5. Submarine Landscapes at Kamchia Depression

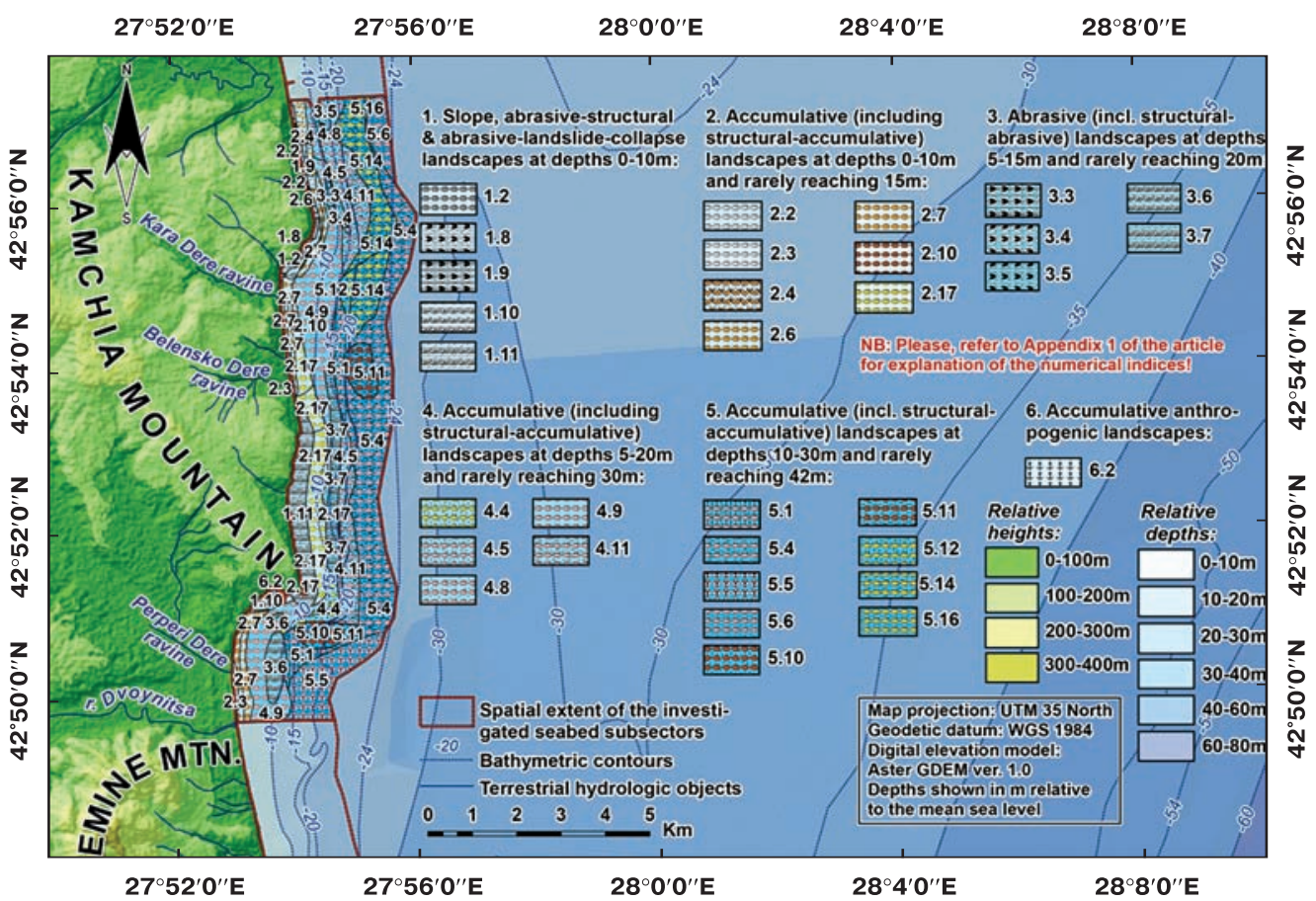

Fig. 6. Submarine Landscapes at Kamchia Mountain coastal area 


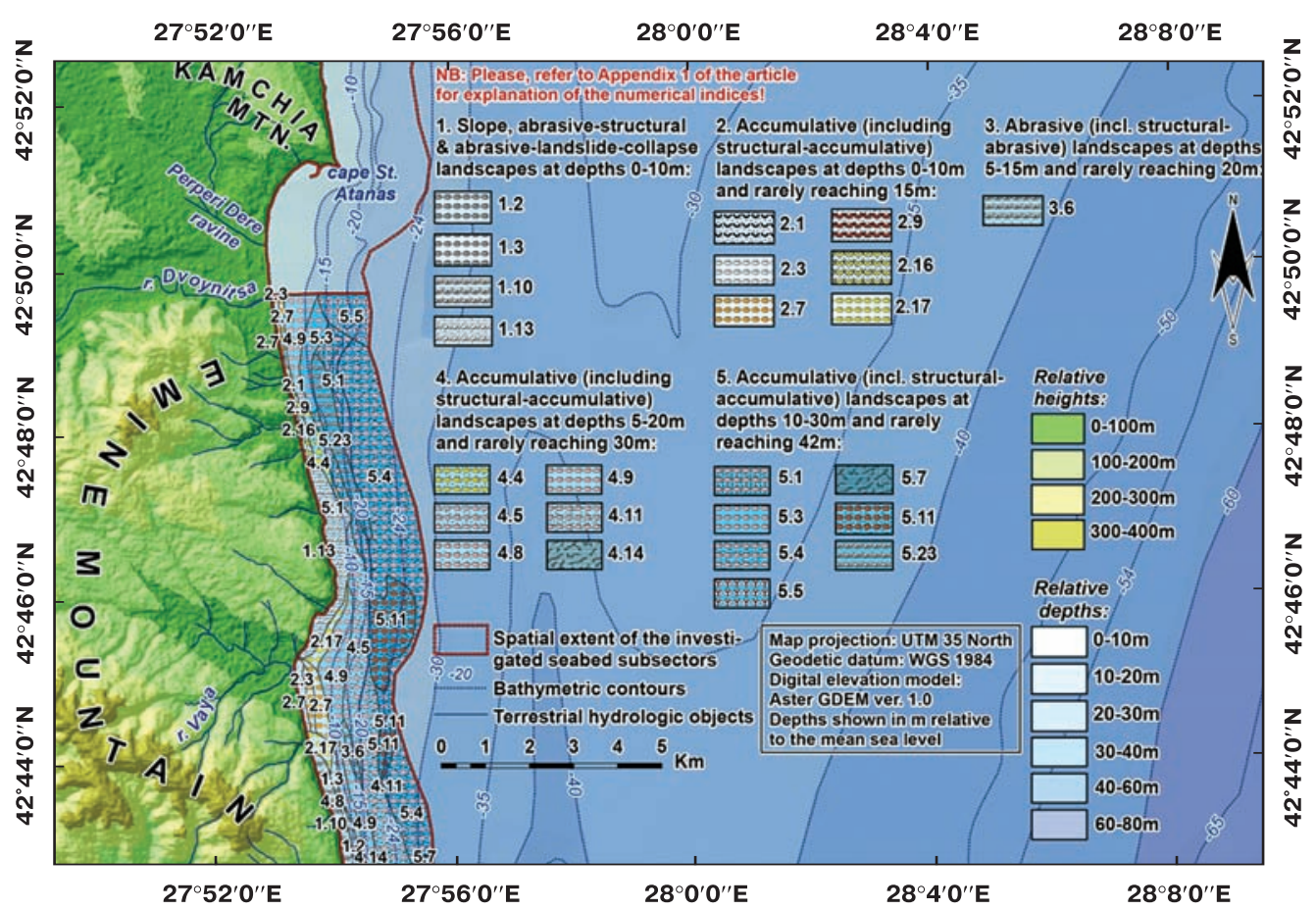

Fig. 7. Submarine Landscapes at Emine Mountain coastal area (Northern Part)

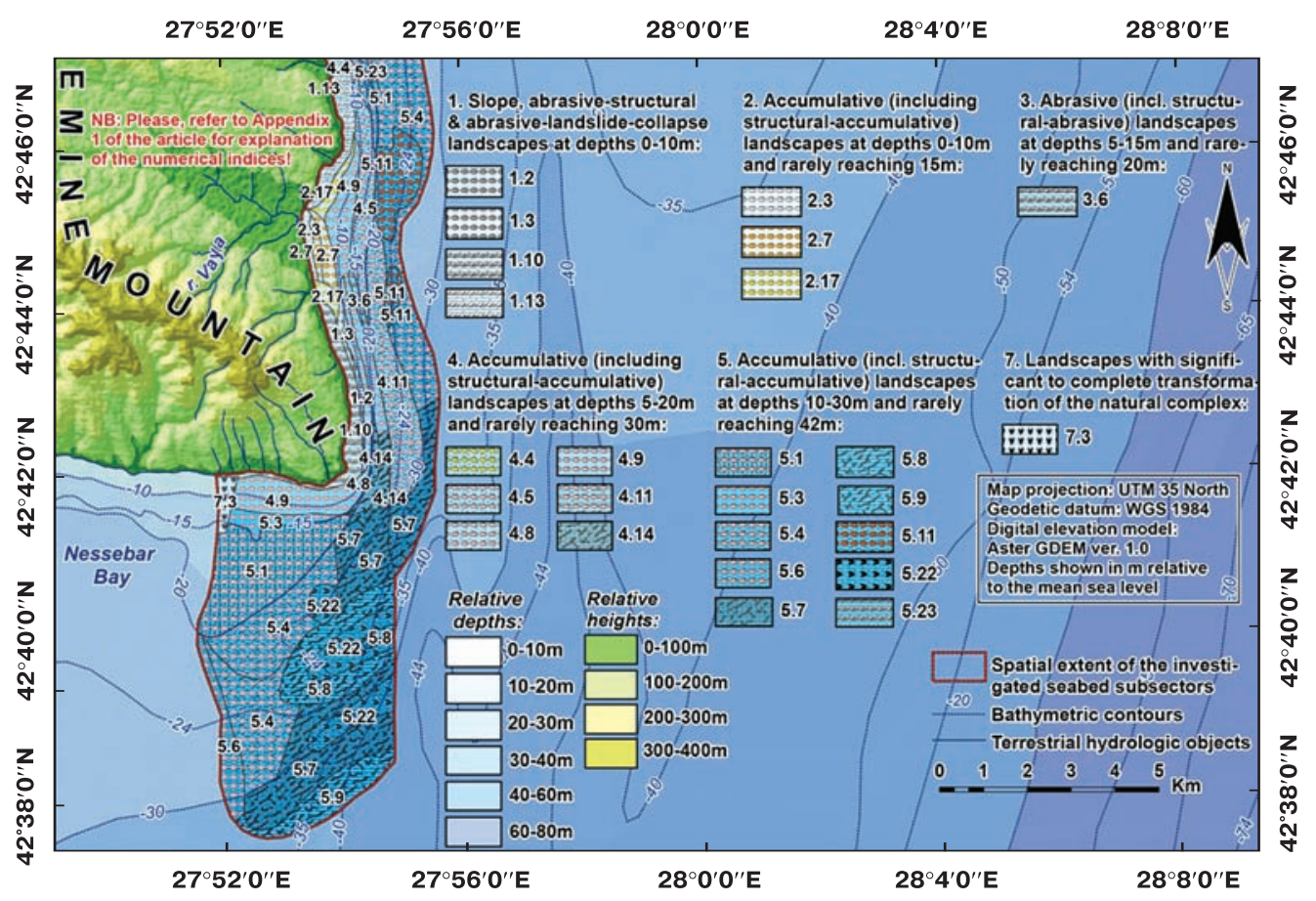

Fig. 8. Submarine Landscapes at Emine Mountain coastal area (Southern Part) 


\section{LEGEND KEY}

\section{A. Conditionally natural landscapes of the submarine coastal slope}

\section{Landscapes of the shallow geo- and morphodynamically active zone}

1. Slope, abrasive-structural and abrasive-landslide-collapse landscapes at depths 0-10 m:

1.1. Abrasive landscapes at structural slopes, with coarse sand and infauna dominated by Donacidae, Veneridae etc. clams, developed at depths 3-7 m; 1.2. Abrasive landscapes at structural slopes, with medium sand and infauna dominated by Donacidae, Corbulidae, Veneridae, Tellinidae, Arcidae etc. clams, developed at depths 3-7 m; 1.3. Abrasive landscapes at structural slopes, with fine sand and infauna dominated by Corbulidae, Veneridae, Tellinidae, Arcidae etc. clams, developed at depths $2-10 \mathrm{~m} ; 1.4$. Abrasive landscapes at landslide and landslide-collapse plantigrade slopes, with coarse sand and infauna dominated by Donacidae, Veneridae etc. clams and Polychaeta worms, developed at depths 3-7 m; 1.5. Abrasive landscapes at landslide and landslide-collapse plantigrade slopes, with medium sand and infauna dominated by Donacidae, Corbulidae, Veneridae, Tellinidae, Arcidae etc. clams, developed at depths 2-10 m; 1.6. Abrasive landscapes at landslide and landslide-collapse plantigrade slopes, with unsorted medium and fine sand and infauna dominated by Donacidae, Corbulidae, Veneridae, Tellinidae, Arcidae etc. clams, developed at depths 2-10 m; 1.7. Abrasive landscapes at landslide-structural-plantigrade slopes of conglomerates overgrown by Mytilidae mussels and Cystoseira spp. brown algae, developed at depths $0-10 \mathrm{~m} ; \mathbf{1 . 8}$. Abrasive landscapes at landslide-structural-plantigrade slopes of sandstones overgrown by Mytilidae mussels and Cystoseira spp. brown algae, developed at depths $0-10 \mathrm{~m} ; \mathbf{1 . 9}$. Landscapes of the geogenic reefs and rocky banks of sandstones overgrown by Mytilidae mussels and green and red annual algal communities, developed at depths $0-10 \mathrm{~m}$; 1.10. Abrasive landscapes at landslide-structural-plantigrade slopes of flysch, with communities of Pholadidae rock-boring clams and overgrown by Cystoseira spp. brown algae, developed at depths 0-10 m; 1.11. Abrasive landscapes at landslide-structural-plantigrade slopes of marls, with communities of Pholadidae rock-boring clams and overgrown by Cystoseira spp. brown algae, developed at depths 0-10 m; 1.12. Abrasive landscapes at landslide-structural-plantigrade slopes of marls, with communities of Pholadidae rock-boring clams and overgrown by green and red annual algal communities, developed at depths $0-10 \mathrm{~m} ; \mathbf{1 . 1 3}$. Abrasive landscapes at landslide-structural-plantigrade slopes of limestones, with communities of Veneridae rock-boring clams and overgrown by Mytilidae mussels and Cystoseira spp. brown algae, developed at depths $0-10 \mathrm{~m}$

2. Accumulative (including structural-accumulative) landscapes at depths 0-10 $\mathrm{m}$ and rarely reaching $15 \mathrm{~m}$ :

2.1. Accumulative forebeach landscapes, with unsorted coarse and medium sand and infauna dominated by Mesodesmatidae, Donacidae etc. clams and Polychaeta worms, developed at depths 0-7 m; 2.2. Accumulative forebeach landscapes, with medium sand and infauna dominated by Donacidae, Corbulidae, Veneridae, Tellinidae, Arcidae etc. clams, developed at depths 3-7 m; 2.3. Accumulative forebeach landscapes, with fine sand and infauna dominated by Corbulidae, Veneridae, Tellinidae, Arcidae etc. clams, developed at depths 0-7 m; 2.4. Accumulative landscapes at wave-formed bars, with medium sand and infauna dominated by Mesodesmatidae, Donacidae etc. clams and Polychaeta worms, developed at depths 0-7 m; 2.5. Accumulative landscapes at wave-formed bars, with coarse sand and infauna dominated by Donacidae, Veneridae etc. clams and Polychaeta worms, developed at depths 3-7 m; 2.6. Accumulative landscapes at wave-formed bars, with medium sand and infauna dominated by Donacidae, Corbulidae, Veneridae, Tellinidae, Arcidae etc. clams, developed at depths 3-7 m; 2.7. Accumulative landscapes at wave-formed bars, with fine sand and infauna dominated by Corbulidae, Veneridae, Tellinidae, Arcidae etc. clams, developed at depths 0-10 m; 2.8. Accumulative landscapes at wave-formed bars, with sandy silt and burrows of thalassinidean shrimps or infauna dominated by Veneridae, Tellinidae etc. clams, developed at depths 7-10 m; 2.9. Accumulative landscapes at contemporary submarine terraces, with unsorted coarse and medium sand and infauna dominated by Mesodesmatidae, Donacidae etc. clams and Polychaeta worms, developed at depths 0-7 m; 2.10. Accumulative landscapes at contemporary submarine terraces, with fine sand and infauna dominated by Corbulidae, Veneridae, Tellinidae, Arcidae etc. clams, developed at depths 3-7 m; 2.11. Slope-accumulative landscapes, with coarse sand and infauna dominated by Veneridae, Tellinidae etc. clams and Polychaeta worms, developed at depths $10-15 \mathrm{~m} ; 2.12$. Slope-accumulative landscapes, with medium 
sand and infauna dominated by Donacidae, Corbulidae, Veneridae, Tellinidae, Arcidae etc. clams, developed at depths 3-7 m; 2.13. Slope-accumulative landscapes, with fine sand and infauna dominated by Corbulidae, Veneridae, Tellinidae, Arcidae etc. clams, developed at depths 0-15 m; 2.14. Slopeaccumulative landscapes, with sandy silt and burrows of thalassinidean shrimps or infauna dominated by Veneridae, Tellinidae etc. clams, developed at depths 7-10 m; 2.15. Slope-accumulative landscapes, with silt and infauna dominated by Veneridae, Mactridae, Semelidae, Cardiidae etc. clams, developed at depths $10-15 \mathrm{~m} ; \mathbf{2 . 1 6}$. Geostructurally formed accumulative landscapes, with coarse sand and infauna dominated by Mesodesmatidae, Donacidae etc. clams and Polychaeta worms, developed at depths 0-7 m; 2.17. Geostructurally formed accumulative landscapes, with fine sand and infauna dominated by Corbulidae, Veneridae, Tellinidae, Arcidae etc. clams, developed at depths 0-15 m

\section{Landscapes of the weakly active medium-depth zone}

3. Abrasive (including structural-abrasive) landscapes at depths 5-15 $\mathrm{m}$ and rarely reaching $20 \mathrm{~m}$ :

3.1. Abrasive landscapes at structural terraces, with medium sand and infauna dominated by Donacidae, Corbulidae, Veneridae, Tellinidae, Arcidae etc. clams, developed at depths 5-10 m; 3.2. Abrasive landscapes at structural terraces, with unsorted medium and fine sand and infauna dominated by Corbulidae, Veneridae, Tellinidae, Arcidae etc. clams, developed at depths 5-10 m; 3.3. Landscapes of the geogenic reefs and rocky banks of sandstones overgrown by Mytilidae mussels and green and red annual algal communities, developed at depths 5-10 m; 3.4. Landscapes of the geogenic reefs and rocky banks of sandstones overgrown by Mytilidae mussels and Cystoseira spp. brown algae, developed at depths 8-15 m; 3.5. Landscapes of the rocky banks of sandstones overgrown by Mytilidae mussels, sponges, hydrozoans etc., developed at depths $10-20 \mathrm{~m} ; 3.6$. Landscapes of the geogenic reefs and rocky banks of flysch, with communities of Pholadidae rock-boring clams and overgrown by Cystoseira spp. brown algae, developed at depths 5-15 m; 3.7. Landscapes of the rocky banks of marls, with communities of Pholadidae rock-boring clams and overgrown by Cystoseira spp. brown algae, developed at depths 5-15 m

\section{Accumulative (including structural-accumulative) landscapes at depths 5-20 m and rarely rea- ching $30 \mathrm{~m}$ :}

4.1. Landscapes of the accumulative bars of medium sand with infauna dominated by Corbulidae, Veneridae, Tellinidae, Arcidae etc. clams, developed at depths 10-12 m; 4.2. Landscapes of the accumulative bars of sandy silt with burrows of thalassinidean shrimps or infauna dominated by Veneridae, Tellinidae etc. clams, developed at depths 10-12 m; 4.3. Landscapes of the structural bars of coarse sand with infauna dominated by Veneridae, Tellinidae etc. clams and Polychaeta worms, developed at depths $10-20 \mathrm{~m}$; 4.4. Geostructurally formed slope-accumulative landscapes, with coarse sand and infauna dominated by Donacidae, Veneridae, Tellinidae etc. clams, developed at depths 7-15 m; 4.5. Geostructurally formed slope-accumulative landscapes, with coarse sand and infauna dominated by Veneridae, Tellinidae etc. clams and Polychaeta worms, developed at depths 8-20 m; 4.6. Geostructurally formed slope-accumulative landscapes, with coarse sand partially covered by blocks, boulders and shells overgrown by Mytilidae mussels, green and red annual algal communities and infauna dominated by Veneridae, Tellinidae etc. clams, developed at depths 5-7 m; 4.7. Geostructurally formed slopeaccumulative landscapes, with medium sand partially covered by blocks, boulders and shells overgrown by Mytilidae mussels, green and red annual algal communities and infauna dominated by Corbulidae, Veneridae, Tellinidae, Arcidae etc. clams, developed at depths 8-12 m; 4.8. Geostructurally formed slope-accumulative landscapes, with medium (rarely heterogeneous) sand and infauna dominated by Donacidae, Corbulidae, Veneridae, Tellinidae, Arcidae etc. clams, developed at depths 5-15 m; 4.9. Geostructurally formed slope-accumulative landscapes, with unsorted medium and fine sand and infauna dominated by Corbulidae, Veneridae, Tellinidae, Arcidae etc. clams, developed at depths 8-15 m; 4.10. Geostructurally formed slope-accumulative landscapes, with fine sand and infauna dominated by Veneridae, Tellinidae etc. clams and Polychaeta worms, developed at depths 15-20 m; 4.11. Geostructurally formed slope-accumulative landscapes, with unsorted shelly sand and infauna dominated by Mytilidae, Veneridae, Tellinidae etc. bivalves, developed at depths 20-30 m; 4.12. Geostructurally formed slope-accumulative landscapes, with sandy silt and burrows of thalassinidean shrimps or infauna dominated by Veneridae, Tellinidae etc. clams, developed at depths $10-20 \mathrm{~m} ; \mathbf{4 . 1 3}$. Geostructurally 
formed slope-accumulative landscapes, with silt and infauna dominated by Veneridae, Mactridae, Semelidae, Cardiidae etc. clams and Polychaeta worms, developed at depths 10-15 m; 4.14. Geo-structurally formed slope-accumulative landscapes, with unsorted sand and epifaunal mussel beds of Mytilus galloprovincialis, developed at depths $15-25 \mathrm{~m} ; \mathbf{4 . 1 5}$. Accumulative landscapes at structural terraces, with unsorted medium and fine sand and infauna dominated by Corbulidae, Veneridae, Tellinidae, Arcidae etc. clams, developed at depths 8-12 m; 4.16. Accumulative landscapes at structural terraces, with sandy silt and burrows of thalassinidean shrimps or infauna dominated by Veneridae, Tellinidae etc. clams, developed at depths 10-12 m

\section{Landscapes of the inactive deep-water zone}

\section{Accumulative (including structural-accumulative) landscapes at depths $10-30 \mathrm{~m}$ and rarely reaching $42 \mathrm{~m}$ :}

5.1. Slope-accumulative and platform-accumulative landscapes with unsorted coarse and fine sand and infauna dominated by Veneridae, Tellinidae etc. clams and Polychaeta worms, developed at depths $15-20 \mathrm{~m}$; 5.2. Slope-accumulative and platform-accumulative landscapes, with medium sand and infauna dominated by Donacidae, Corbulidae, Veneridae, Tellinidae, Arcidae etc. clams, developed at depths $10-15 \mathrm{~m} ;$ 5.3. Slope-accumulative and platform-accumulative landscapes, with fine sand and infauna dominated by Corbulidae, Veneridae, Tellinidae, Arcidae etc. clams, developed at depths 10-15 $\mathrm{m}$; 5.4. Slope-accumulative and platform-accumulative landscapes, with unsorted shelly sand and infauna dominated by Mytilidae, Veneridae, Tellinidae etc. bivalves, developed at depths 20-30 m; 5.5. Slope accumulative and platform-accumulative landscapes, with sandy silt and burrows of thalassinidean shrimps or infauna dominated by Veneridae, Tellinidae etc. clams, developed at depths 10 $20 \mathrm{~m} ;$ 5.6. Slope-accumulative and platform-accumulative landscapes, with silt and infauna dominated by Veneridae, Mactridae, Semelidae, Cardiidae etc. clams and Polychaeta worms, developed at depths 10-30 m; 5.7. Slope-accumulative and platform-accumulative landscapes, with unsorted sand and epifaunal mussel beds of Mytilus galloprovincialis, developed at depths 20-42 m; 5.8. Slope-accumulative and platform-accumulative landscapes, with sandy silt and epifaunal mussel beds of Mytilus galloprovincialis, developed at depths $20-42 \mathrm{~m}$; 5.9. Slope-accumulative and platform-accumulative landscapes, with silt and epifaunal mussel beds of Mytilus galloprovincialis, developed at depths 12-42 $\mathrm{m} ; \mathbf{5 . 1 0}$. Geostructurally formed accumulative landscapes at structural terraces, with coarse sand and infauna dominated by Veneridae, Tellinidae etc. clams and Polychaeta worms, developed at depths 12$20 \mathrm{~m}$; 5.11. Geostructurally formed accumulative landscapes at structural terraces, with unsorted shelly sand and infauna dominated by Mytilidae, Veneridae, Tellinidae etc. bivalves, developed at depths $20-25 \mathrm{~m} ; \mathbf{5 . 1 2}$. Geostructurally formed accumulative landscapes at structural slopes and structural depressions, with unsorted coarse and medium sand and infauna dominated by Veneridae, Tellinidae etc. clams and Polychaeta worms, developed at depths $12-20 \mathrm{~m} ; \mathbf{5 . 1 3}$. Geostructurally formed accumulative landscapes at structural slopes and structural depressions, with unsorted medium and fine sand and infauna dominated by Corbulidae, Veneridae, Tellinidae, Arcidae etc. clams, developed at depths $12-15 \mathrm{~m} ; \mathbf{5 . 1 4}$. Geostructurally formed accumulative landscapes at structural slopes and structural depressions, with unsorted shelly sand and infauna dominated by Mytilidae, Veneridae, Tellinidae etc. bivalves, developed at depths $20-25 \mathrm{~m} ; \mathbf{5 . 1 5}$. Geostructurally formed accumulative landscapes at structural slopes and structural depressions, with sandy silt and burrows of thalassinidean shrimps or infauna dominated by Veneridae, Tellinidae etc. clams, developed at depths $13-20 \mathrm{~m}$; 5.16. Geostructurally formed accumulative landscapes at structural slopes and structural depressions, with silt and infauna dominated by Veneridae, Mactridae, Semelidae, Cardiidae etc. clams and Polychaeta worms, developed at depths $20-25 \mathrm{~m} ; \mathbf{5 . 1 7}$. Landscapes of the structural bars, with coarse sand and infauna dominated by Veneridae, Tellinidae etc. clams and Polychaeta worms, developed at depths $12-20 \mathrm{~m} ; \mathbf{5 . 1 8}$. Landscapes of the structural bars, with sandy silt and burrows of thalassinidean shrimps or infauna dominated by Veneridae, Tellinidae etc. clams, developed at depths $12-20 \mathrm{~m}$; 5.19. Landscapes of the rocky banks of conglomerates overgrown by Mytilidae mussels and Cystoseira spp. brown algae, developed at depths $10-15 \mathrm{~m} ; \mathbf{5 . 2 0}$. Landscapes of the rocky banks of sandstones overgrown by Mytilidae mussels and green and red annual algal communities, developed at depths 10$12 \mathrm{~m} ;$ 5.21. Landscapes of the geogenic reefs and rocky banks of sandstones overgrown by Mytilidae mussels, sponges, hydrozoans etc., developed at depths 12-20 m; 5.22. Landscapes of the rocky banks 
of sandstones with epifaunal mussel beds of Mytilus galloprovincialis, developed at depths 22-42 m; 5.23. Landscapes of the rocky banks of flysch, with communities of Pholadidae rock-boring clams developed at depth 10-20 m; 5.24. Landscapes of the rocky banks of marls, with communities of Pholadidae rock-boring clams and Cystoseira spp. brown algae, developed at depth 10-12 m

\section{B. Anthropogenic submarine landscapes}

IV. Landscapes with significant to full modification of the seabed substrates and the associated macrobenthic biological communities

6. Accumulative anthropogenic landscapes:

6.1. Accumulative landscapes in the wave-shadow zone near hydrotechnical structures; 6.2. Port and harbor areas

7. Landscapes with significant to complete transformation of the natural complex:

7.1. Navigable canals; 7.2. Stationary pound nets; 7.3. Installations for mariculture farming.

Among the good features of the contemporary period is the initiation of the NATURA 2000 project in the country and along the Bulgarian Black Sea coast in particular. Nine protected sites are established within the study area in compliance with Directive 2009/147/EC (Birds Directive) and eight more according to Directive 92/43/EEC (Habitats Directive) (www.natura2000.moew.government.bg). Among the remarkable properties of present-day nature conservation in the country is the designation of marine protected areas, as well as the scientifically motivated strive towards achievement of spatio-ecological coherence among the NATURA 2000 sites in the Bulgarian Black Sea (Todorova et al., 2015). Nonetheless, the questions concerning habitat mapping, (marine) spatial planning, regulation and zoning of the land use at these areas remain open.

\section{Conclusions}

The results of the investigations can draw the following main conclusions:

- Total sum of the positive elements of the sediment balance in the Bulgarian Black Sea coast (cliff erosion and bench abrasion, solid runoff, biogenic sedimentation and aeolian drift) is estimated at 4,857,400 Mg/y;

- At present, The Bulgarian Black Sea coastal zone is characterized with prevalence of erosion $\left(236,000 \mathrm{~m}^{3} / \mathrm{y}, 467,000 \mathrm{Mg} / \mathrm{y}\right)$ over accretion $\left(10,000 \mathrm{~m}^{3} / \mathrm{y}, 16,000 \mathrm{Mg} / \mathrm{y}\right)$. Hence, it may be concluded that despite being in a phase of geomorphic maturity the observed substantial imbalance in the sediment budget comes as a result of humaninduced interventions;

- The most negatively affected shoreline subsectors at the investigated region by means of coastal erosion are cape Kaliakra - cape Ekrene, Varna coastal area (cape Ekrene - cape Galata), as well as Kamchia coastal zone (cape Paletsa - cape Karaburun). Nevertheless, while the issues concerning abrasion, landslide activity, disturbed sediment transport and progressive sand strip erosion at the first two subsectors come primarily as a consequence of excessive technogenic load, these at KamchiyskoShkorpilovski beach are due to decreased solid runoff of the river Kamchia that followed after the creation of four reservoirs in its catchment basin. Presently, the river discharges in the Black Sea coastal zone approximately $462.000 \mathrm{t} / \mathrm{y}$ of solid load, which is only $22 \%$ of the possible quantities under natural conditions (2.106.000 t/y). As a consequence, disturbance in the sediment balance and further reduction of the cited beach in front of the river mouth is expected; 
- Dynamics of the coastal and shallow submarine landscape complexes (Fig. 1-8, see color plate), as well as the associated changes in their landscape structure, are inseparably linked to the contemporary coastal geomorphic processes, ongoings anthropogenization, shoreline and land use dynamics taking place at the national sector of the Black Sea coastal zone. This statement implies for the necessity of a landscape-based rather than ecosystem-based marine spatial planning and integrated coastal zone management in Bulgaria.

\section{Acknowledgements}

Authors would like to express their sincere gratitude to former and current colleagues from Department «Coastal Zone Dynamics» at IO-BAS for the provided grey literature on beach erosion and accretion rates within the coastal sector between cape Ekrene and cape Paletsa.

\section{REFERENCES}

1. Antsyferov S., Belberov Zdr., Massel S. (Eds.). Dynamical processes in coastal regions. Sofia: «Prof. Marin Drinov» academic publ. house, 1990. - 190 p.

2. Agarkova-Lyakh I.V. Natural complexes of coastal area of North-Western and Western Crimea with intensive bidirectional material flows between land and sea // Scientific Notes of Taurida National V.I. Vernadsky University. - Series: Geography. — 2011. - 24 (63), No 1. - P. 35-44 (in Russian).

3. Bogouslavskiy A.S., Kazakov A.S., Kuznetsov A.S. Factors for geoecological hazards at Crimean Mountains coastal zone // Journal of the Eurasian Union of Scientists. - 2015. - 4 (13), № 11. P. 109-112 (in Russian).

4. Brossard J., Duperret A. Coastal chalk cliff erosion: experimental investigation on the role of marine factors // In: Mortimore R. N., Duperet A. (Eds.) Coastal Chalk Cliff Instability; Geological Society Engineering. Geology Special Publications. - 20. - London : Geol. Soc. of London, 2004. - P. 109-120.

5. Byala beach dossier. Varna: Scientific fund of the Institute of Oceanology «Professor Fridtjof Nansen», Varna - Bulgarian Academy of Sciences, 1992 (in Bulgarian).

6. Dachev $V$. Genesis and evolution of Varna Central Beach // Proceedings of the Institute of Oceanology - Bulgarian Academy of Sciences. - Varna, 2003. - 4. - P. 74-82 (in Bulgarian).

7. Dachev V., Genov R. Accompanying effects of marine construction on the Bulgarian Black Sea coast // Proceedings of the Institute of Oceanology - Bulgarian Academy of Sciences. - Varna, 1998. - 2. - P. 120-126 (in Bulgarian).

8. Dachev V., Nikolov Hr. Integral changes of the accumulative sectors between cape Cherni nos and «Albena» maritime resort // Oceanology. - 1977. - 2. - P. 57-64 (in Bulgarian).

9. Davidson-Arnott R. Coastal sediment transport // An introduction to coastal processes and geomorphology. - Cambridge: Cambridge University Press, 2010. - P. 139-180.

10. Dimitrov D. 2010. Geology and Non-traditional resources of the Black Sea. - LAP (Lambert Academic Publishing AG). - 2010. - 244 p.

11. Dimitrov P., Solakov D., Peychev V., Dimitrov D. The source provinces in the Black Sea // Proceedings of the Institute of Oceanology / Bulgarian Academy of Sciences. - Varna, 2003. - 4. P. 29-35.

12. Duperret A., Genter A., Martinez A., Mortimore R.N. Coastal chalk cliff instability in NW France: role of lithology, fracture pattern and rainfall // Mortimore R. N., Duperet A. (Eds.) Coastal Chalk Cliff Instability. Geological Society Engineering. Geology Special Publications. - 20. London : Geol. Soc. of London, 2004. - P. 33-56.

13. Essin N.V., Moskovkin V.M., Dmitriev V.A. On the theory for management of the abrasion process // Zenkovich V.P. et al. (Eds.) Natural fundamentals of coastal protection. Moscow : Nauka, 1987. P. 5-18 (in Russian).

14. Goudie A. Alphabetical glossary of geomorphology, version $1.0 / /$ Electronic edition of the International Association of Geomorphologists (IAG). - 2014. - $84 \mathrm{p}$.

15. Huggett R.J. Coastal landscapes. Coastal erosional landforms. Chapter 13 // Gerrard, J. (Ed.) Fundamentals of Geomorphology, Second Edition; Routledge Fundamentals of Physical 
Geography Series. - London-New York: Routledge Taylor and Francis Group, 2007. P. $320-325$.

16. Ivanov K., Marinov Iv., Panayotov T., Petkov Al. Lakes. Coastal lakes. Chapter XI // Hydrology of Bulgaria. - Sofia : Nauka i Izkustvo, 1961. - P. 252-261 (in Bulgarian).

17. Irakli beach dossier. Varna: Scientific fund of the Institute of Oceanology «Professor Fridtjof Nansen» / Bulgarian Academy of Sciences. - Varna,1992 (in Bulgarian).

18. Kanchev I., Gercheva Y. Geologic map of Bulgaria. Map sheet Dolni Chiflik (with explanatory notes) / Publication of the Geology and Mineral Resources Committee, Enterprise for Geophysical Research and Geologic. - Mapping, 1992 (in Bulgarian).

19. Kara Dere beach dossier. Varna: Scientific fund of the Institute of Oceanology «Professor Fridtjof Nansen» // Bulgarian Academy of Sciences. - Varna, 1992 (in Bulgarian).

20. Keremedchiev St., Peychev V. Contemporary geomorphodynamic activity and stability of the coastal slope stretching between cape Galata and the mouth of Sakama Dere ravine // Bulletin of the Union of Scientists. - Varna, 2001. - 1-2. - P. 67-71 (in Bulgarian).

21. Keremedchiev St., Trifonova E., Valchev N., Andreeva N., Eftimova P., Demireva D. PLANCOAST spatial planning of Varna coastal area between cape Ekrene and cape Paletsa. Final project report. Varna: Scientific fund of the Institute of Oceanology «Professor Fridtjof Nansen». - Bulgarian Academy of Sciences. - Varna, 2007 (in Bulgarian).

22. Masselink G., Auger N., Russel P., O'Hare T. Short-term morphological change and sediment dynamics in the intertidal zone of a macrotidal beach // Sedimentology. - 2007. - 54 (1). P. 39-53.

23. Mortimore R. N., Lawrence J., Pope D., Duperret A., Genter A. Coastal cliff geohazards in weak rock: the UK Chalk cliffs of Sussex / Mortimore R.N., Duperet A. (Eds.) Coastal Chalk Cliff Instability. Geological Society Engineering Geology Special Publications. - 20. London : Geol. Soc. of London, 2004. - P. 3-32.

24. Nikolov Hr., Dachev V., Keremedchiev St. Morphology and dynamics of the river Kamchia coastal zone // Proceedings of III National Congress of Geographers in Bulgaria, October 1973, Varna (manuscript in Bulgarian).

25. Obzor beach dossier. Scientific fund of the Institute of Oceanology «Professor Fridtjof Nansen» / Bulgarian Academy of Sciences. - Varna, 1992 (in Bulgarian).

26. Peychev $V$. The abrasion process along the Bulgarian Black Sea coast // Marinski Y. et al. (Eds.) Protection and long-term stabilization of the slopes of the Black Sea coast. - Sofia : Prof. Marin Drinov, 1998. - P. 139-142 (in Bulgarian).

27. Peychev $V$. Morphodynamical and lithodynamical processes in the coastal zone. - Varna : Slavena, 2004. - 231 pp. (in Bulgarian).

28. Peychev V., Dimitrov D. Oceanology. - Varna : Ongal, 2012. - 490 p. (in Bulgarian).

29. Peychev V., Peev P., Stanchev Hr. New data about the rates of abrasion along the Bulgarian Black Sea coast // Proceedings of the Institute of Oceanology / Bulgarian Academy of Sciences. 2005. - 5. - P. 170-180 (in Bulgarian).

30. Popov Vl., Mishev K. Geologic-tectonic structure and lithostratigraphic prerequisites for formation of the up-to-date relief of the coast and the shelf // Geomorphology of the Bulgarian Black Sea coast and shelf. Sofia : Prof. Marin Drinov, 1974. - P. 35-49 (in Bulgarian).

31. Prodanov B., Kotsev I., Keremedchiev St., Todorova V., Dimitrov L. Initial assessment of the technogenic pressure in the mediolittoral zone of the Bulgarian Black Sea coast // Proceedings of the Second European SCGIS conference «Conservation of Natural and Cultural Heritage for Sustainable Development: GIS-based Approach» (September 24, 2013, Sofia, Bulgaria). P. 4-13, [Electronic resourse]. - Available at: http://proc.scgis.scgisbg.org/index2014.html

32. Resulov G. Main guidelines in coastal protection activities // Bregozashtita'89. - Sofia : Stroitelstvo i arhitectura, 1989. - P. 3-7 (in Bulgarian).

33. Rosati J.D., Kraus N.C. Formulation of sediment budget at inlets. Coastal Engineering Technical Note IV-15 of the US Army Corps of Engineers, 1999. - 20 pp.

34. Simeonova G. Coastal protection against erosion along the Bulgarian Black Sea // Journal of Coastal Research. - 1992. - 8 (3). - P. 745-751.

35. Shuiskiy Y.D., Popov Vl. The sediment transport along the Bulgarian Black Sea coastal zone // Priroda, 1977. - 2. - P. 43-47 (in Bulgarian). 
36. Shuiskiy Y.D., Schwartz M.L. Basic principles of sediment budget study in the coastal zone // Shore and Beach, 1983. - 5(1). - P. 34-41.

37. Shuiskiy Y.D., Simeonova G. About the distribution of the erosive cliff types in the Bulgarian sector of the Black Sea coast // Engineering geology and hydrogeology. - 1982. - 12. - P. 11-21 (in Bulgarian).

38. Stoykov D. Initiation and development of geoprotection activity along the (Bulgarian) Black Sea coast // Marinski Y. et al. (Eds.) Protection and long-term stabilization of the slopes of the Black Sea coast. - Sofia : Prof. Marin Drinov, 1998. - P. 11-19 (in Bulgarian).

39. Stoykov S., Pironkov P. New data concerning the geologic structure of the coastal zone between cape Galata and the village of Byala, Varna Region // Geologia i neftogazonosnost. - Sofia : Tehnika, 1981. - P. 15-25 (in Bulgarian).

40. Todorova V, Dimitrov L, Doncheva V, Trifonova E, Prodanov B. Benthic habitat mapping in the Bulgarian Black Sea // Proceedings of the XII International Conference on the Mediterranean Coastal Environment (MEDCOAST' 2015). (October 6-10, 2015, Varna). - Bulgaria (in press).

41. Trifonova E., Stancheva M. Features in dynamics and development of the beaches from cape Kaliakra to gully Momchilov Dol // Proceedings of the Institute of Oceanology / Bulgarian Academy of Sciences. - 2003. - 5. - P. 229-238 (in Bulgarian).

42. Vikhovanets G.V. 1999. Aeolian processes and forms development on coasts to Ukraine // Geogr. Fisica e Dinam. Quat. - Torino, 1999. - 22. - P. 99-105.

43. Wolters G., Müller $G$. The propagation of wave impact induced pressures into cracks and fissures // Mortimore R.N., Duperet A. (Eds.) Coastal Chalk Cliff Instability; Geol. Soc. Engineering Geology Special Publications. - 20. London : Geol. Soc. of London, 2004. - P. 121-130.

44. www.natura2000.moew.government.bg (Last accessed on February 1, 2016).

Статья поступила 11.05.2016

\section{И. Коцев, Д. Димитров, В. Пейчев}

\section{СОВРЕМЕННЫЕ ТЕНДЕНЦИИ В СОСТОЯНИИ ЛАНДШАФТОВ И ДИНАМИКИ БЕРЕГОВОЙ ЛИНИИ БОЛГАРСКОГО СЕКТОРА ЧЕРНОГО МОРЯ}

Проанализировано современные процессы естественной и подверженной антропогенному влиянию динамики береговой линии между мысом Калиакра и мысом Емине на болгарском побережье Черного моря. Основное внимание уделено воздействию антропогенных факторов на береговую морфодинамику, прибрежную эрозию, транспортировку и аккумуляцию осадков под влиянием изменений в использовании земель и техногенной нагрузки. Стадии недавних преобразований ландшафта с начала XX столетия рассмотрены хронологически. Сделаны выводы о взаимоотношениях прибрежных процессов, геоморфологии, динамики использования земли, уровня антропогенизации и изменения прибрежного ландшафта на исследованной территории.

Ключевые слова: динамика береговой линии, эрозионные процессы, баланс осадков, твердый сток, антропогенизация ландшафта.

\section{I. Коцев, Д. Дімітров, В. Пєйчєв}

\section{СУЧАСНІ ТЕНДЕНЦІЇ У СТАНІ ЛАНДШАФТІВ І ДИНАМІКИ БЕРЕГОВОЇ ЛІНІЇ БОЛГАРСЬКОГО СЕКТОРА ЧОРНОГО МОРЯ}

Проаналізовано сучасні процеси природної і зазнавшої антропогенного впливу динаміки берегової лінії між мисом Каліакра і мисом Еміне на болгарському узбережжі Чорного моря. Основну увагу приділено впливу антропогенних чинників на берегову морфодинаміку, прибережну ерозію, транспортування й акумуляцію осадів під впливом змін у використанні земель i техногенного навантаження. Стадії недавніх перетворень ландшафту з початку XX сторіччя розглянуто хронологічно. Зроблено висновки про взаємовідношення прибережних процесів, геоморфології, динаміки використання землі, рівня антропогенізації та зміни прибережного ландшафту на дослідженій території.

Ключові слова: динаміка берегової лінії, ерозійні процеси, баланс осадів, твердий стік, антропогенізація ландшафту. 